\title{
A Thousand and One Rewrites
}

\section{Translating Modernity in the Arabian Nights}

\author{
Nazry Bahrawi \\ Singapore University of Technology and Design \\ and, Middle East Institute, National University of Singapore \\ nazry_bahrawi@sutd.edu.sg
}

\begin{abstract}
Taking its cue from the "cultural turn" move in Translation Studies, this essay argues that modern reimaginings of The Arabian Nights can be seen as attempts at making this classical work relevant to modern sensibilities and aesthetic forms. It will juxtapose the normative versions of the Nights to Edgar Allan Poe's The Thousand-and-Second Tale of Scheherazade (1845) in light of scientism, Naguib Mahfouz's Arabian Nights and Days (1979) from the perspective of political agency, as well as Hanan Al-Shaykh's One Thousand and One Nights (2011) by way of feminism and human rights. This essay posits that the malleability of the Nights to modernist ideas and forms entrenches its stature as an exemplary work of world literature. Lastly and relatedly, this essay will also revisit Lefevere and Bassnett's "rewriting" theory to explore its potential contribution to the nascent discipline of world literature in light of Zhang Longxi's arguments on crosscultural translatability.
\end{abstract}

\section{Keywords}

cultural translation - rewriting - modernity - cross-cultural hermeneutics The Arabian Nights

When it was released in 1960, the cinematic wonder that is Ali Baba Bujang Lapok enthralled the Bahasa-speaking peoples of the Malay Archipelago largely because it was one of the few films to have cast the region's celebrated actor P. Ramlee, hailed then by some as the Elvis Presley of the Malay entertainment scene, as the resident villain. To a critic of comparative literature, though, the true wonder of the film is implied in the first part of its title-Ali Baba. As the 
final installment of the Bujang Lapok comedy trilogy, the hit film appropriates a character from The Arabian Nights, translating him into a relatable protagonist for a modern Malay audience in this Southeast Asian corner of the world. While the film's faithfulness to the text can be gleaned from its use of "a story within a story," it departs from the text through its use of anachronism, wherein modern machinery in the forms of automobiles and motorcycles were jarringly juxtaposed to the film's indisputably premodern Middle Eastern setting. Yet, within the grand system of what can be thought as world culture, Ali Baba Bujang Lapok is not the only modern rendition of the Arabian Nights. Elsewhere, others abound.

From the Disneyfication of Aladdin to the launch of a Scheherazade comic series, the Nights figures alongside a select group of premodern fictions such as Dante's Divine Comedy and Homer's The Odyssey to count as a great work of world literature for its sustained relevance and cross-cultural appeal. ${ }^{1}$ But what is it about The Arabian Nights that continues to fascinate cultures across the modern world? This essay explores this puzzle through the lens of the "cultural turn" in Translation Studies. In particular, it will consider three reimaginings of The Arabian Nights as cultural rewrites to argue that the text's malleability is anchored in its affinity for multitudes in form and content. Thus, this essay deals with the idea of translation as a form of adaptation rather than the quest for linguistic transfer and equivalence as it is normally understood. To this end, it will consider Edgar Allan Poe's 1845 short story The Thousand-and-Second Tale of Scheherazade as well as excerpts from Naguib Mahfouz's novel Arabian Nights and Days (1979, trans. 1995) and Hanan Al-Shaykh's 2011 collection of short stories, One Thousand and One Nights. These works were chosen for reasons of scope. First, they each hail from a chronological period within the phase of "late modernity" defined by Marshall Berman as the period when "the developing world culture of modernism achieves spectacular triumphs in art and thought" (Berman 17). While far from exhaustive, these Nights-inspired literary texts from America and Egypt collectively represent a modest attempt at capturing the geographical breadth implied in Berman's "world culture of modernism". Secondly, the texts can be interpreted in light of differing facets of modernisation. In the case of Poe's short story, this is scientism or the blind faith in the scientific method and thought. Mahfouz's novel can be read from the perspective of democracy and political reform, while Al-Shaykh's collection is peppered with themes of gender equality. Thus, this essay widens the scope

1 The Scheherazade comic series was launched in 2013 by the Us-based comic publisher Big Dog Ink. 
of Berman's "late modernity" phase beyond the twentieth century to include a text from the late nineteenth century (Poe's) and the early twenty-first century (Al-Shaykh's).

Given its ambiguous beginnings, The Arabian Nights inspires cultural rewrites by way of its unique confluence of poetics - namely, its authorless stature, thematic insistence on agency, and narrative style of derivative stories. Yet such an exploration begets a more theoretical concern: how else can the "rewriting" theory in Translation Studies contribute to debates on world literature? Along this line of inquiry, I have elsewhere argued that the deluge of modern literary works challenging dogmatic interpretations of Abrahamic scriptures fits the mould of cultural translation (Bahrawi 2015). In this essay, I propose to broaden the cultural translation thesis by configuring the act of rewriting as rereading, an adjustment that would usher the discourse of cultural translation into the realm of cross-cultural hermeneutics as this has been theorised by Zhang Longxi. How would this adjustment matter? While both acts are prefigured in the process of cultural translation, rereading sees the translator engage closely with the original text in search of novel meanings and fresh perspectives. Rewriting, on the other hand, focuses on the production of a new text that may or may not be congruent with the spirit of the original. In this sense, rereading engages with the "core" of the original with a greater intensity than rewriting. It is this sense of dialogism stemming from rereading that this essay wishes to extract from its analysis.

In his 2012 essay "A Conceptual and Empirical Approach to Cultural Translation," Kyle Conway postulates that cultural translation can either be seen as the process of explaining the thoughts of a primitive tribe to outsiders, or as an interpretative undertaking aimed at expounding the coherent system of signs belonging to a cultural community. The former is anthropological, while assuming superiority on the part of the more "civilised" interpreter. The latter is concerned with the study of semiotics, and does not display what Conway describes as a "teleology of advance towards European civilisation" (Conway 267) that is implicit in the former. Both forms can be described as "rewriting" as their common impulse to interpret culture often results in the production of written texts.

In contrast to Conway, this essay's definition of cultural translation as rewriting refers to a set of ideas that developed out of the "cultural turn" thesis first mooted by Susan Bassnett and André Lefevere in their book Constructing Cultures (1998). There Bassnett argues that translation can no longer be seen simply as an exercise in linguistic transformation. Rather, the study of textual translation must also account for "broader issues of context, history and conventions" (123). This cultural turn was crucial in establishing translation studies 
as an independent academic discipline in the 1980 s and 1990s in many universities across the world. The inception of cultural translation as rewriting was prefigured in Lefevere's 1982 essay "Mother Courage's Cucumbers," which situated texts squarely within the workings of ideology and power. In that essay, Lefevere posits what he calls the "refracted text," or a literary work that gets adapted "to a different audience, with the intention of influencing the way in which that audience reads the work" (4). This later informs his theory of "translation as rewriting" in his seminal book Translation, Rewriting and the Manipulation of Literary Fame (1992). Here, Lefevere argues that translation can be seen as a form of rewriting, alongside other forms that are prone to manipulation in form and content. He writes:

Whether they produce translations, literary histories or their more compact spin-offs, reference works, anthologies, criticism or editions, rewriters adapt, manipulate the originals they work with to some extent, usually to make them fit in with the dominant, or one of the dominant ideological or poetological currents of their time.

8

As Lefevere would expect, questions of ideology and poetics matter in all three of the modern reiterations of The Arabian Nights that I will discuss. Yet it is also the case that all three texts qualify less as "translations" than as "adaptations". For Lefevere's frame to work here, a slight adjustment needs to be made. As I have argued elsewhere, the idea of translation must be understood "as an active process of meaning-making that arises from comprehending, reviewing and adapting established texts and norm" (Bahrawi 256). In that essay, I argue that such a frame qualifies José Saramago's Cain (2009) as a translation in the way it reproduces the biblical story of Cain and Abel as a counter-cultural narrative to religious dogma. In the next few sections, I will consider how cultural rewrites of the Nights by Poe, Mahfouz and Al-Shaykh can also be considered cultural translations for varying reasons.

One final clarification needs to be made pertaining to what is meant by the "original" Nights. It is well documented that Antoine Galland and Richard Francis Burton introduced new stories into the corpus of the Nights in their respective French and English translations. In fact, even the Arabic manuscripts of the Nights which inspired these translators are said to be an intercultural mix of folk stories originating from ancient India, Iran and the Middle East. For instance, the Middle Persian (Pahlavi) text titled Hāzar Afsān (The Thousand Stories) was translated into Arabic as Alf layla wa-laylah (Thousand and One Nights) in the ninth century A.D. (Reynolds 1330). Here, there have been schol- 
arly speculations that the Hāzar Afsān was in turn based on Indian stories such as Kalîla and Dimna as well as the Book of Women's Wiles (Horovitz 393). All these facts suggest that when it comes to the Nights the concept of originality is fraught with complications. For the purpose of this essay, the adjective "original" refers to the compendium of stories that the wider world has come to associate with the Nights - the kernel of which is the frame-story of Scheherazade and Shahriyar, but which also includes the tales of Sindbad, Aladdin and Ali Baba. These last three stories did not appear in the oldest surviving Arabic manuscript of the Nights from fourteenth-century Syria, but were introduced by Galland in his 1704 translation and passed off as part of the Nights manuscript. By "original," then, this paper refers to the themes associated with the Galland version of the Nights; we will be less concerned with Galland's distortions than with cultural rewrites of the Nights compendium as it has become familiar to the world.

Among the three cultural rewrites of The Arabian Nights that I have chosen to analyse, Edgar Allan Poe's The Thousand-and-Second Tale of Scheherazade (1845) must surely account as the most macabre. Instances of terror are peppered throughout Poe's concoction, with the story's ending possibly qualifying as its grimmest moment. Having outlined her incredible tale, the courageous protagonist Scheherazade finds herself suffering the same fate as those she vied to protect; we are told of her subjection to "the tightening of the bowstring" (Poe 372). The nonchalant tenor of this tragic twist makes it both ironic and cold. Within the span of a few pages, Poe's story suggests that the normative Nights of yore, the text that caught Europe by storm as evidenced through its many translations, presents to us a false ending. Read this way, Poe's story offers a fresh take on the Nights in purporting to present a fuller picture of an otherwise definitive tale. On the other hand, his rendering could also be seen as not quite revolutionary. Seen as an outsider's rewriting of an Arabic classical text, Poe's attempt at expanding the Nights' corpus harks back to the expansive efforts of Antoine Galland and Richard Burton.

What qualifies Poe's rewriting as modernist is its playful take on "facts". Indeed, the story begins with the telling epithet "Truth is stranger than fiction," foreshadowing its unravelling of all things scientific. If that is unclear enough, in his opening paragraph Poe goes on to cheekily name the lost Oriental text from which the story is derived, "Tellmenow Isitsöornot". In doing so, Poe's

2 By "modernist," this essay is referring to the tensions, effects and ideas related to a period of human life that saw major changes taking place across the world in the forms of industrialisation, urbanisation, secularisation, the rise of nation-states and the advent of logic and reason. 
expert interjection as a master-weaver of Gothic tales transforms what most consider to be a canonical Middle Eastern folkloric tale into a work of postsecular comedy-horror. By "postsecular" here, I am referring to the refusal to assume the existence of "a pure nature outside that realm of belief, a nature that is the domain of pure facts" assumed in secular thought (Smith 226). Instruments of science that were referenced in the story belong to this domain of pure facts. The following quotation in which Scheherazade describes a coal train is a case in point:

Among the magicians, were domesticated several animals of very singular kinds; for example, there was a huge horse whose bones were iron and whose blood was boiling water. In place of corn, he had black stones for his usual food; and yet, in spite of so hard a diet, he was so strong and swift that he would drag a load more weighty than the grandest temple in this city, at a rate surpassing that of the flight of most birds.

POE 368

Strange as it may be, the coal train is presented in the above quotation as a living, breathing creature juxtaposed with other verifiable living things ("birds" and "a huge horse"). Elsewhere in the story, Scheherazade's descriptions of the steamship, the telegraph and the calculator take a similar tack. In all of these cases, scientific products are postulated as a natural element of the secular world.

The presence of inventions contemporaneous to Poe's text imbues his story with an air of anachronism, in a manner similar to Ali Baba Bujang Lapok. But if the film does this for comic effect, Poe's story seems to have a more serious intention. Here, we can see Sindbad's eighth voyage as a séance of sorts, one that conjures up mythical creatures of the future, creatures enabled by human engineering, as a means of chastising what can be seen as an expression of human overreach. The story's postsecular impulse is best embodied in King Shahriyar, whose responses to Scheherazade's creatures become progressively coherent in the way they move from "Hum!", "Pshaw!" and "Fal al!" to "Absurd!", "Preposterous!" and finally "Stop!". At first glance, the trajectory of his utterances can be read as mirroring humanity's progress from irrational belief to secular reason. But these utterances collectively present a paradoxShahriyar's forward march to cogency is begotten with the introduction of more and more "science" by Scheherazade. To Shahriyar, these offspring of Science are even more incredible than the cryptozoological man-eating giant and roc of Sindbad's first seven journeys. Unable to take it any longer, Shahriyar succumbs to his former bestial self by executing yet another of his wives. Ultimately, the 
inability to translate science into magic implied in Poe's story can be understood in terms of Manav Ratti's reading of the postsecular as the untranslatable: "The postsecular is the sign of not just the limits of translation ... but also of untranslatability itself" (Ratti 136). These inventions in Poe's story cannot be naturalised, lending credence to the claim that "science" cannot be translated. What is needed in understanding the secular, clarifies Ratti, is "a new form of interpretation, one which does not recode prior interpretative systems" (ibid.). This call for the unearthing of a new hermeneutics coincides with the thoughts of Poe's Scheherazade, who in her final moments takes refuge in the fact that "much of the history remained untold" (Poe 372).

Like Poe, in Arabian Nights and Days (1979, trans. 1995) Mahfouz imagines the morning after Scheherazade's thousandth and one tale. Its sombreness is expressed through Scheherazade's falling out of love, possibly signalling the Egyptian author's mood surrounding his subject matter-despotism and political abuse. This is made painfully clear at one point in the novel when Shahriyar says to his wife: "The truth ... is that your body approaches while your heart turns away" (Mahfouz 217). If Poe's story can be seen as fashioning earlier versions of the Nights into a critique of scientism, Mahfouz's novel finds as its target the political practices of his day. To this end, Mahfouz shifts the reader's focus from Scheherazade to Shahriyar, pushing the latter into the limelight as a semi-protagonist in search of repentance. The novel reinvents three aspects of the Nights, in a response to modernity.

First, by way of genre, Mahfouz reinscribes the folkloric tale as a postmodern bildungsroman that recounts Shahriyar's metamorphosis from tyrant to democratic leader. The postmodern feature in Shahriyar's transformation is expressed most explicitly in the way his story morphs into that of Harun Al-Rashid, as Wen-Chin Ouyang points out (408). Al-Rashid, who ruled the Abbasid empire as caliph in the ninth century, is also a staple character in several stories in older renditions of the Nights. Here, "The Sultan" tells the story of Shahriyar and his two advisers disguising themselves as foreign merchants, mirroring earlier renditions that saw Al-Rashid embarking on a similar expedition for the purpose of observing the ways in which justice and order are maintained in his city. Mahfouz's story becomes self-reflexive as Shahriyar meets with another version of himself, a false sultan in the guise of Ibrahim the water-carrier who, is seeking justice for his wrongly executed son, Aladdin. It is through this instance of mimicry that the real Shahriyar is alerted to the injustice permeating his land, just as the text—in mimicking the original Nightsseems to draw its readers' attention to the injustices of 1970s Egypt.

Related to genre is the fact that Mahfouz's novel can be categorised as what Rasheed El-Enany has described as marhalat al-shakl al-asīl aw al-turāthī, or 
"the phase of indigenous or traditional form" in Mahfouz's career (El-Enany xi). The author's recourse to the use of episodic narration and, most importantly, magical realism, positions the novel not so much as a work of fantasy or science fiction, but as a political allegory of the troubles then facing Egypt. Tahia Abdel Nasser points to several instances that she believes informed "disturbances in the medieval quarter in Mahfouz's novel, which reflects corruption, political oppression, and the rise of religious fundamentalism" (Nasser 546). Specifically, Nasser outlines the 1972 student movement, the 1977 Bread Riots, the 1979 opposition to the Egyptian-Israeli peace treaty, and the 1981 arrests of more than a thousand intellectuals.

Thirdly, in terms of narrative technique, Mahfouz's novel presents a melding of the frame story and its framed stories, such that characters between the two co-exist within the same sphere, breaking their respective fourth walls, so to speak. The simultaneity of Mahfouz's multiple character arcs is also the reason why Shahriyar can only qualify as a semi-protagonist. In this borderless world of Mahfouz's Nights, there is a very real sense that the fates of other characters matter. The novel's other protagonists include the executed Gamasa al-Bulti, who re-appears throughout the novel as well as Scheherazade herself, whose degradation from the hopeful heroine of the people to just another wife trapped in a loveless marriage renders mundane a hitherto extraordinary tale.

The example of Mahfouz's Sindbad is particularly pertinent. With Sindbad now directly recounting his adventures to Shahriyar, the tale takes a didactic turn. Unlike the Nights of yore, Mahfouz's tale privileges lessons over narratives. While this robs Shahriyar (and the reader) of the power to interpret, it serves the purpose of moving both to action-thus encouraging political agency. This works, at least, in the case of Shahriyar who takes Sindbad's stories to be the straw that breaks the camel's back. He first internalises the lessons by repeating to himself Sindbad's words: "Traditions are the past and of the past there are things that must become outdated" (Mahfouz 214). Then, right after their meeting, he tells Scheherazade that he has to leave her:

'We all extol your merits.'

Without heeding her words, he said: 'Do you know why I kept you close by me? Because I found in your aversion a continued torment that I deserved. What saddens me is that I believe that I deserve punishment.'

She should not stop herself from crying, and he said gently, 'Weep, Sharzad, ${ }^{3}$ for weeping is better than lying.'

3 Denys Johnson-Davies, the translator of Naguib Mahfouz's Arabian Nights and Days, spells 
'I cannot,' she exclaimed, 'lead a life of ease and comfort after tonight.' 'The palace is yours,' he said in protest, 'and that of your son who will be ruling the city tomorrow. It is I who must go, bearing my bloody past.' 217

Unlike earlier versions of the Nights, it is Shahriyar, not Scheherazade, who is the master manipulator here. By turning the tables, Mahfouz inadvertently suggests that tyrants can reform, that they too possess the political will to repent and change for the better. In Mahfouz's hopeful rewriting of the Nights, Sindbad has not delineated what is arguably the text's most important lesson-the notion that political agency can bring about a better society. Here, the carnivalesque, rebellious spirit that punctuates Mahfouz's novel is personified through the character of Gamasa Al-Bulti, who sacrifices himself to the cause of justice by killing his city's corrupt governor, before admitting to committing this act so that he can be punished accordingly. After his execution, Al-Bulti reappears throughout Mahfouz's story first as Abdullah the porter and then as a raving madman, serving as a figurative reminder that corruption is still rife, suggesting that political agency is a moral imperative that demands constant attention.

While Scheherazade can easily be seen as the true hero of the "original" Nights, it is surprising that few modern adaptations have chosen to embolden her feminist valour. In fact, the opposite is true in a case such as Big Dog Ink's Scheherazade comic series, whose covers hark back to images of exotic Arab women that had appeared in nineteenth-century orientalist paintings by European artists such as Adrien Henri Tanoux and Jean-Léon Jérôme. Enter Hanan Al-Shaykh. As the only Arab female author to have rewritten the Nights, Al-Shaykh makes up for lost opportunities by inscribing into it the theme of power and its subversions, making hers possibly the cultural rewrite most congruent to the modernist ethics of human rights. At the risk of sounding too didactic, Al-Shaykh clearly outlines her motivation in the foreword to One Thousand and One Nights (2013) when she writes:

[A]s a female Arab writer my real enchantment was the discovery that women in those forgotten ancient societies were far from passive and fearful; they showed their strong will and intelligence and wit, all the time recognising that their behaviour was the second nature of the weak and oppressed.

AL-SHAYKH X

Scheherazade as "Sharzad" in his text. I have decided to stick to this spelling given that the above is a direct quotation. 
To this end, it is notable that her rendition, as opposed to Poe's and Mahfouz's, is one that departs least from the "original" Nights. While there are certainly stark differences that would qualify her work as "a new re-imagining" of the Nights as the second part of her title suggests, Al-Shaykh's stories do not depart radically from the core of the "original" version. Her novel still focuses on the relationship between the frame story of Scheherazade and Shahriyar, rather than what transpires after the thousandth and one tale as in the cases of Poe and Mahfouz. Though her stories are selectively chosen and told with some variations, they follow a similar trajectory to that of the original. Al-Shaykh's version too begins with the cuckolding of Shahriyar, which is then followed by Scheherazade's request to be married to him, much to her father's chagrin. Even the order of Scheherazade's stories is somewhat akin — the fisherman and the djinni, the three dervishes, and Sindbad near the end.

Having said this, it must be pointed out that there are also some marked exceptions in Al-Shaykh's novel; thus the story of the porter and three ladies has been moved to the very end, whereas this tale appears much earlier in the original. Still, relatively speaking, Al-Shaykh's rewrite compared to Poe's and Mahfouz's can be said to be the most faithful. Read from the frame of the gendered metaphorics of translation, Al-Shaykh's rendition qualifies as traditionally feminine because "like women, the adage goes, translations should either be beautiful or faithful" (Chamberlain 455). For Chamberlain, this association between femininity and fidelity speaks to a patriarchal view of translation in which the differences between the "original" and its "translation" are expressed as productive and reproductive work respectively. Such a gendered view is premised on the belief that the best kinds of translation are those that do not stray from the original.

Indeed, this idea of faithfulness makes an appearance in Al-Shaykh's final story, "The Resolution of the Porter and the Three Ladies," in which Su'ād, a beautiful Bedouin woman, makes the extraordinary choice to remain married to her poor husband instead of accepting Harun Al-Rashid's offer to wed her. The following poem that she recites in response to the Caliph's offer further extols the virtues of fidelity:

Neither silver, gold, nor marble palaces tempt me

All I yearn for is my wretched hungry man

He who once owned camels and horses

Until Fate herself bertrayed him

My bliss is here with him

Reliving our golden years, 
I'll remain thus

Until the wind of fortune turns.

AL-SHAYKH 287

At first glance, Al-Shaykh's text suggests a disparity between form and content, in that its form is feminine, and its content, feminist. Yet its insistence on fidelity subverts power on two fronts. The first is the obvious challenge to patriarchy represented by the rejection of Caliph Al-Rashid, a powerful man who is used to getting things done his way. Secondly, the seeming disparity between form and content points to the gulf of difference between two types of feminism - the Western ideal of an independent woman who can decide her own fate on her own terms (choosing to be unfaithful should she wish it), and the Islamicate idea that feminine qualities such as modesty and faithfulness can also be seen as feminist. By way of its discrepancy between form and content, Al-Shaykh's text suggest that the "faithful" translations are not always the product of patriarchy, thereby complicating Chamberlain's thesis.

\section{Cultural Rewrites as Cross-Cultural Hermeneutics}

All three rewritings of the Nights display highly imaginative reworkings of the original. Yet their high degree of autonomy brings to mind David Damrosch's cautionary words: "even a reader with universalist principles should also object to a translation that simply assimilates the foreign work entirely to contemporary American values, a process that gets us to no common ground beyond our own local cultural position" (Damrosch 427). Damrosch may be referring to John L. Forster's "modernist" translation of the ancient Egyptian lyrical poem "The Contendings of Horus and Seth," but his point is just as germane to this essay. Can these cultural rewritings of the Nights be considered bad translations because they fail to adequately capture "the force and beauty of the original"? (ibid. ${ }^{426-7)}$ ). This is a question that crisscrosses between the disciplines of Translation Studies and world literature.

To begin answering it is to consider the notion of cross-cultural hermeneutics raised by Zhang Longxi. According to Zhang, Thomas Kuhn's idea of incommensurability, which arose out of his attempt to explain the evolution of scientific thought in the form of divergent paradigms, has influenced the social sciences and the humanities in less than productive ways. For some scholars in these latter disciplines, Zhang argues, Kuhn's incommensurability has been taken as a mantra for upholding "a dichotomous view of cultures and societies and thus precipitates the fragmentisation of the social fabric and the isolation 
of different groups" (Zhang Cross-cultural 371). When incorporated into the study of human civilisations, Kuhn's notion of incommensurability makes real the "clash of civilisation" thesis championed by Samuel Huntington in assuming that cultures are inherently unique and thus incommensurable from each other. Classifying this mode of thinking as cultural relativism, Zhang points to the fundamental flaw in the way it "minimises differences within cultures so that differences between cultures can be pushed to the foreground" (Complexity 346). Zhang points to the example of Jacques Derrida's postulation that Chinese written characters are the antithesis to the logocentric Western writing that privileges thought over writing. To Zhang, such misreading poses a challenge to cross-cultural understanding. He counter-proposes the paradigm of cross-cultural translatability from the perspective of world literature, arguing that this is premised on "the universalibility of hermeneutic questions despite differences and the possibilities of misunderstanding" (Cross-cultural 377).

Zhang's postulation can aid us in considering cultural rewritings of The Arabian Nights. As explicated above, the three adaptations of the Nights are not simply rewritings of the original text; they are in fact also rereadings. Clearly, each text has corresponded with the original with an intent to highlight specific concerns about their times. These texts have also crossed cultures, transporting the classical version of the Nights from premodern Baghdad to nineteenthcentury America, Egypt of the 1970s, and twenty-first century Britain. Seeing them not just as cultural productions but as cultural interpretations thus coincides with Zhang's call to recognise cross-cultural translatability as "a new paradigm in the study of different cultures in this globalised world of ours" (377). Yet, the question remains: Are these rewritings so far removed from the original that they can no longer qualify as translations?

While all three rewritings did drastically change aspects of the "original" Nights, it can also be argued that they retain a sense of its core and can still qualify as translations. First, they each focus on the power of narratives to shape lives. In fact, the complexity through which they imaginatively use plot and frame stories only serves to emulate the beauty of the narrative techniques of the original. The second point also relates to the idea of aesthetics and form. All three rewritings play with the original's structure of frame and framed stories as a means of championing their message. Here, Poe's and Mahfouz's versions can be seen as "lost" framed stories to the "original" Nights. Meanwhile, AlShaykh's twist ending, in which an unnamed shopper in Scheherazade's final story begins to recount the story of Scheherazade and Shahriyar to a gathering of men, collapses the division between frame and framed stories, while also injecting a sense of self-reflexivity to the text and its readers. 
Finally, with regard to "force," these rewritings lend credence to non-normative ideals of their time that can be distilled as postsecularism with Poe's tale, revolutionary zeal with Mahfouz's version, and Islamic feminism with AlShaykh's. This echoes the brazen spirit of the "original" Nights. Pinault points to at least one instance in Islamic history where the Nights was subjected to censorship. This transpired in AD 932 when Al-Suli declared that some newly arrived books meant for his tutee, Muhammad, son of the 'Abbasid caliph Al-Muqtadir, were safe for consumption because they were "not like the books [others] read excessively, such as The Wonders of the Sea, The Tale of Sindbad, and The Cat and the Mouse" (qtd. in Pinault 2). Ultimately, viewing these cultural rewritings, or rereadings, of the Nights as translations sheds new light on the question of the universalism of literary texts. While differences are real and productive, there is also a changeable core that gets transported across cultures, time and space. That "core" is not so much the idea of a single, eternal truth, but the residue of that which had once inspired its readers, a fleeting sense of worldliness that is reclaimable and reproducible in new forms. George Steiner describes the hermeneutical motion in translation as "the act of elicitation and the appropriative transfer of meaning" (Steiner 570). It is only through the recognition of translation as a cross-cultural hermeneutical act, as Zhang postulates, that we can attempt to grasp that malleable meaning.

\section{Works Cited}

Al-Shaykh, Hanan. One Thousand and One Nights: A Retelling. London and New York: Bloomsbury, 2013.

Bahrawi, Nazry. "Not my Bible's Keeper: Saramago's Cain Translates Postsecular Dissent." In Reading the Abrahamic Faiths: Rethinking Religion and Literature, ed. Emma Mason. London and New York: Bloomsbury, 2015.

Bassnett, Susan. "The Translation Turn in Cultural Studies." In Constructing Cultures: Essays on Literary Translation, eds. Susan Bassnett and André Lefevere. Clevedon: Multilingual Matters, 1998.

Berman, Marshall. All that is Solid Melts into Air: The Experience of Modernity. London and New York: Penguin, 1988 (1982).

Chamberlain, Lori. "Gender and the Metaphorics of Translation." Signs 13:3 (1988), 45472.

Conway, Kyle. "A Conceptual and Empirical Approach to Cultural Translation." Translation Studies 5: 3 (2012), 264-79.

Damrosch, David. “Translation and World Literature." In The Translation Studies Reader (Third Edition), ed. Lawrence Venuti. London and New York: Routledge, 2000. 
El-Enany, Rasheed. Naguib Mahfouz: The Pursuit of Meaning. London and New York: Routledge, 1993 .

Horovitz, Josef. "The Origins of the Arabian Nights." In The Arabian Nights, ed. Daniel Heller-Roazen. New York and London: W.W. Norton and Company, 2010.

Lefevere, André. "Mother Courage's Cucumbers: Text, System and Refraction in a System of Literature." Modern Language Studies 2: 4 (1982), 3-20.

Lefevere, André. Translation, Rewriting and the Manipulation of Literary Fame. London and New York: Routledge, 1992.

Mahfouz, Naguib. Arabian Nights and Days. Trans. Denys Johnson-Davies. New York: Anchor Books, 1995 (1979).

Ouyang, Wen-Chin. "Metamorphoses of Scheherazade in Literature and Film." Bulletin of the School of Oriental and African Studies 66: 3 (2003), 402-18.

Pinault, David. Story-telling Techniques in The Arabian Nights. Leiden and New York: Brill, 1992.

Poe, Edgar Allan. "The Thousand-and-Second Tale of Scheherazade." In The Arabian Nights, ed. Daniel Heller-Roazen. New York and London:W.W. Norton and Company, 2010.

Ratti, Manav. The Postsecular Imagination:Postcolonialism, Religion and Literature. London and New York: Routledge, 2013.

Reynolds, Dwight. "The Thousand and One Nights." In Encyclopedia of the Novel. Volume 2. $M-Z$, eds. Paul Schellinger, Christopher Hudson and Marijke Rijsberman. London and New York: Routledge, 1998.

Smith, Anthony Paul. "Postsecularism: Introduction." In Reading the Abrahamic Faiths: Rethinking Religion and Literature, eds. Emma Mason and Nazry Bahrawi. London and New York: Bloomsbury, 2015.

Steiner, George. After Babel: Aspects of Language and Translation. New York: Open Road Media, 2013 (1975).

Tahia, Abdel Nasser. "Revolution and Cien Años de soledad in Naguib Mahfouz's Layali Alf Laylah." Comparative Literature Studies 52: 3 (2015), 499-561.

Zhang, Longxi. "Cross-cultural Translatability: Challenges and Prospects." European Review 23: 3 (2015), 369-78.

Zhang, Longxi. "The Complexity of Difference: Individual, Cultural, and Cross-Cultural." Interdisciplinary Science Reviews. Special Issue: History and Human Nature 35: 3-4 (2010), 341-52. 